\title{
Mind the Gap: Political Analysis, Public Expectations and the Parliamentary Decline Thesis
}

\author{
Matthew Flinders and Alexandra Kelso \\ British Journal of Politics and International Relations \\ (2011), Volume 13, Number 2, pp.249-268.
}

\begin{abstract}
The parliamentary decline thesis formed the dominant theory and narrative of legislative behaviour and capacity during the 20th century. And yet in analytical terms the thesis provides a relatively blunt instrument for dissecting complex socio-political relationships. The bluntness of this tool has not been remedied by the lazy thinking and unconscious theorising that has too often dominated research in this field. The central argument of this article is that the dominant public, media and academic perception of an eviscerated and sidelined parliament provides a misleading caricature of a more complex institution. Moreover the constant promotion and reinforcement of this caricature by scholars arguably perpetuates and fuels public disengagement and disillusionment with politics.
\end{abstract}

Keywords: gap analysis; parliamentary decline; legislative studies; professional responsibilities

Matthew Flinders, Department of Politics, University of Sheffield, Sheffield S10 2TY, UK, email:m.flinders@sheffield.ac.uk

Alexandra Kelso, Department of Politics and International Relations, University of Southampton, Southampton S017 1BJ, UK, email: a.kelso@soton.ac.uk 
Political science, like most disciplines, is based on the implicit acceptance of certain idioms, assumptions and theories. These baseline positions generally convey a simple line of reasoning and have at times become almost 'essentially uncontested' (cf. Gallie 1956) foundations of the discipline. Within legislative studies the parliamentary decline thesis (PDT) dominated accounts of political behaviour and dynamics throughout the 20th century. However, the PDT was, and still is, deeply flawed, yet these flaws have never been comprehensively demonstrated by legislative scholars, some of whom have in fact produced research that does successfully pinpoint its various fallacies. The prevalence of the PDT, combined with the failure of contradictory research to inform broader academic arguments, has meant that the thesis has restricted scholarly research in the field, encouraged academics to promote crude assumptions rather than undertaking detailed research, and most importantly may have contributed to the erosion of public support for politics by advancing a powerful (but false) view of parliamentary impotence that does little to foster public interest, faith or engagement in politics.

This article is therefore concerned not only with challenging theories, methods and evidence that have been deployed to sustain a narrative about legislative decline but is also seeking to make a much broader and bolder argument concerning the duties and obligations of political scientists to cultivate public understanding and political literacy. Many scholars will not like this argument-we can hear the quills being sharpened as we write-but the increasing blame that commentators are placing at the door of political science for fuelling the erosion of public support [p.250] for politics demands examination. In February 2010, for example, Peter Riddell challenged the PDT and criticised the political science community for failing to provide an accurate or sufficiently sophisticated account of Westminster politics. For Riddell the PDT was 'a gross over-simplification ... the declinists are wrong in their view of both the past and the present ... [the] demonization of the whips is naïve and ill-informed'. This failure to understand Westminster was, for Riddell, symptomatic of the fact that political scientists had spent too long in an enclosed and narcissistic world of 'academics writing for each other' and too little time in the Palace of Westminster or with politicians (Riddell 2010, 549). Tony Wright MP (2009) ploughed similar ground when he used the 2009 Political Quarterly Annual Lecture to call for a more accurate and balanced account of legislative-executive interactions, and that 'social scientists start writing in good plain English'.

This article has some sympathy with the recent arguments of Riddell and Wright and therefore offers an argument that is unapologetically critical and provocative. Its argument is rooted in a chain of causation that focuses attention on the role of (dominant) ideas in structuring and influencing political analysis. The perpetuation of the PDT represents an extreme example of lazy thinking and the failure of scholars collectively not only to reflect on dominant disciplinary assumptions but also to communicate effectively more sophisticated accounts of parliament to the media and 
the broader public. This article aims to take issues of ontology, epistemology and methodology seriously and through this generate a more sophisticated account of legislative-executive behaviour. More precisely, this article seeks to develop and refine the analytical leverage of what is termed 'the politics of public expectations' in order to reflect back, on how scholars have assessed legislative behaviour and capacity, and look forward, in terms of generating an evidence-based account of the realities (rather than the mythology) of parliamentary politics. This article is therefore concerned with formulating and verifying a more rigorous way of thinking about the role of legislatures and the capacity of parliamentarians through applied theory.

The article consists of four main sections. The first outlines a general theory of public expectations couched in terms of an 'expectations gap' and then relates this to both practitioner and scholarly accounts of political behaviour. In the second section a process of 'travelling' (see below) occurs whereby this general theory is exported into the sphere of legislative studies as a way of contributing a new perspective, challenging dominant assumptions and understanding the link between the outputs of political analysis and societal outcomes. The core argument is that scholars have expanded the 'expectations gap' by continually regurgitating an over-simplistic PDT that overinflates expectations of what parliament was ever intended, expected or resourced to deliver. In order to develop this point the third section takes the analysis one step further by demonstrating how a more refined and arguably more accurate historical grasp of constitutional development and design, coupled with a more sophisticated account of intra-party and intra-legislative dynamics, leads to a far less critical account of parliament's performance. Put slightly differently, when gauged and assessed against a more realistic set of expectations, parliament's performance and capacity are categorically less poor than the PDT suggests. The final (fourth) section briefly restates the central argument being made and why it matters.

[p.251] Before reviewing what might be termed 'the politics of public expectations' in the first section it is necessary to restate our baseline position. We are not arguing that the balance of power has not shifted from legislatures to executives in many parliamentary democracies around the world. Certainly in the post-war era, executives have dramatically expanded both their public policy universes and their capacity to operate within them, while legislatures have not benefited from increases in institutional resources and capacity of a commensurate magnitude. To this extent the PDT is correct. Our argument, rather, is more subtle. The PDT has over-stated the extent of this shift in the constitutional balance of power, it has failed to acknowledge that parliamentary democracy was founded on the principle of 'strong government' and did not therefore include a proactive or assertive role for the legislature, and it has largely overlooked the existence of informal, but no less important, executive control mechanisms. Scholars may have inadvertently played a key role in widening the 'expectations gap' and therefore contributed to the erosion of political support. As such this article focuses attention on the professional and public responsibilities of legislative 
and constitutional scholars in disseminating an accurate and evidence-based account of political phenomena.

\section{The Politics of Public Expectations}

One of Giovanni Sartori's most influential contributions to political analysis was his distinction between conceptual stretching and travelling. Conceptual stretching suggests the distortion occurring when a concept developed for one set of cases is extended to additional cases to which the features of the concept do not easily apply. As he argues, 'the net result of conceptual straining is that our gains in extensional coverage tend to be matched by losses in connotative precision' (Sartori 1970, 1035). In contrast, conceptual travelling denotes the successful application of a conceptual framework or approach into a new area of intellectual endeavour. This section-and indeed this article-engages in an experiment in conceptual travelling. The fields of public policy analysis, political behaviour, marketing and behavioural economics offer a rich seam of material on 'gap analysis' (i.e. the generation of public expectations and the potential pathologies of unrealistic or overinflated public demands (see, for example, James 2009). This theoretically informed body of literature provides a fresh perspective on the PDT, one that may provoke disciplinary debate and reflection by emphasising the professional obligations of political scientists in terms of cultivating public understanding of politics.

The relationship between the governors and the governed in any polity is based upon the creation and management of certain expectations. In terms of the public's expectations of politics this generally manifests itself in the form of specific assumptions, beliefs and demands about how politicians should behave, how institutions should interact and the level of services they can reasonably expect from the state. These expectations will be ex post-based upon their previous experience of politicians and political behaviour-or ex ante-based upon the promises and commitments they are given by political parties at election time.

However, as many scholars have argued-notably Anthony Downs in his Economic Theory of Democracy (1957) - the incentives and sanctions structure associated with [p.252] conventional forms of democratic engagement arguably encourages politicians to promise standards of behaviour, levels of public services and institutional relationships that are unrealistic and unattainable. Having inflated public expectations the subsequent performance of those politicians undermines public confidence, thereby fuelling disenchantment and apathy. The focus on the creation, management and potential pathologies of public expectations therefore provides away of understanding and teasing apart a central driver of the trend towards political disenchantment that has been discussed under the themes of 'disaffected democracies' (Pharr and Putnam 2000), 'critical citizens' (Norris 1999) and 'why we hate politics' (Hay 2007). 
A central element of this theory is the notion of an 'expectations gap' between what the public expects (or has been led to expect) and those levels of services, behaviour, relationships, etc. that can realistically be provided by politics and the state (see Figure 1). The 'expectations gap' therefore consists of the difference between the public's expectations of what politics should deliver, and what it can realistically deliver given the resource framework and socioeconomic context it is expected to govern within. In terms of seeking to close the gap there are three main strategies:

Option (1) increasing supply (moving the bottom bar upwards-Figure 1);

Option (2) reducing demand (moving the top bar down); or

Option (3) a combination of Options 1 and 2 (close the gap from above and below).

Figure 1 The Expectations Gap

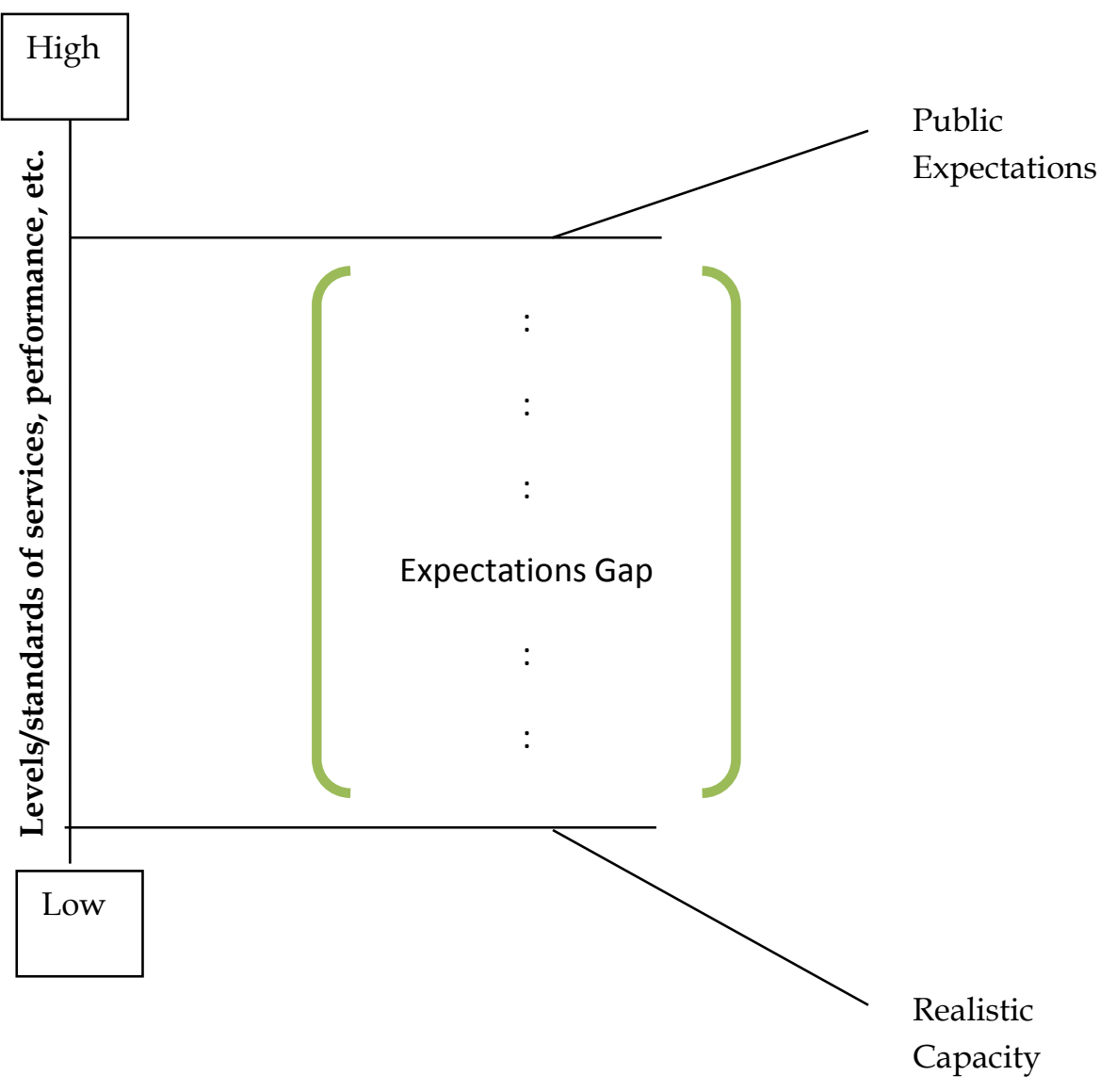


This schema has empirical origins. As director of the British Prime Minister's Policy Unit (1997-2001), David Miliband sought to emphasise that the government's [p.253] modernisation agenda for public services was not going to increase supply dramatically (Option 1). A marginal increase in performance might be delivered but it was never going to close the 'expectations gap'. Miliband therefore argued that the most important role for ministers was actually suppressing, shaping and managing public expectations about what the government could achieve, or at the very least not inflating them further-Option 2 (see Rawnsley 2001, 330).

This 'real world' understanding of the politics of public expectations could be developed into a broader discussion on the literature linking evidence of increasing public disillusionment, disengagement and dissatisfaction with politics to the mismatch between public expectations and governmental performance (see, for example, Bok 1997; Barnes and Gill 2000; Flinders 2009). The puzzle that this literature presents is that public support for politics appears to be eroding in advanced liberal democracies at a time when on almost every indicator (levels of social security, civil rights, educational provision, etc.) government performance is increasing. This puzzle raises a number of questions concerning the capacity of politicians, and to a lesser extent their advisers and officials, to control, shape and manage the public's expectations of what a political system can deliver. It also raises questions about the duties of scholars in informing public debate and projecting balanced and evidence-based accounts of performance and political relationships.

However, the 'expectations gap' is just one facet of this dilemma. There is also the pressing problem within existing socio-political relationships in terms of the 'perception gap'. A lack of trust in politics can produce a situation in which the public become so jaded in their view that they are unwilling or unable (or both) to appreciate and believe that in some policy areas the political system, via the institutions of the state, can and does deliver high-quality services. This produces a critical distinction between the existence of political goods and the perception that political goods are being delivered. The public's perception of the degree to which the political system is 'working' is linked to this article's earlier focus on economic theories of democracy. The context or environment of politics is one that is imbued with a positivity offset and negativity bias (i.e. an emphasis on focusing on problems and allocating blame) arising from a societal context that is often interpreted as low-trust high-blame. Being held to account in the political sphere, as scholars such as Robert Behn (2001), Jonathan Koppell (2005) and Mark Bovens (2006) have emphasised, rarely involves a balanced review of performance but more commonly involves an exercise in problem amplification and blame allocation. More broadly, however, the existence of a contextual or societal positivity offset and negativity bias can lead to a situation in which the public no longer believes that politics or the state are capable of achieving their expectations about the services and levels of provision they should deliver-irrespective of their actual performance. 
Even more interesting from the context of political disengagement and revitalising politics, however, is the fact that research suggests that the public frequently fail to perceive or believe that public services have improved even when their own individual experience of services has been better than expected. This is illustrated in a series of surveys, notably in the research conducted by Ipsos/MORI for the Public Services Trust (2010) inquiry into what the public want, need and expect from public services, which have focused on public services (health, education, transport, etc.) [p.254] and have revealed a significant disparity or 'perception gap' between how the public perceives services (generally negatively) as opposed to their actual experience (generally positive). A similar 'perception gap' can be identified in relation to public trust in MPs. The public's trust in their own constituency MP tends to be significantly higher than levels of trust in MPs more generally (see Birch and Allen 2010).

The 'perception gap' can be understood as a mirror image of the 'expectations gap'. In the latter the public expect too much, because the political system incentivises false or unrealistic promises, and the public are ultimately disappointed; but in the former the political system actually delivers public goods but the public fail to believe or perceive that this is the case. The 'perception gap' adds a new layer to our understandings of political disenchantment and raises distinctive questions about the role of the PDT in possibly exacerbating and reinforcing an unnecessarily negative public conception of politics.

The 'politics of public expectations and perceptions' provides a framework against which we can analyse the PDT that dominated British legislative studies in the $20^{\text {th }}$ century, and thus evaluate the extent to which this thesis may have unwittingly contributed to expanding the 'expectations gap' and contributing, at least in part, to increasing levels of political disenchantment.

\section{Expanding the Gap: The Parliamentary Decline Thesis}

In its simplest manifestation, the PDT suggests that the executive became gradually more ascendant over the legislature during the 20th century. This section provides an overview of this thesis, explores some of the variations and sub-strands within it, and then briefly teases apart what is distinctive about this body of work. Its core argument is that British legislative studies in the 20th century was largely dominated by texts that lamented the decline of parliament but arguably failed to offset that decline against an appreciation and acceptance that Bagehot's 'efficient secret' (1968 [1867]) — the near complete fusion of the executive and legislature-existed by design rather than by accident. The parliamentary state was designed and intended to be a power-hoarding rather than power-sharing polity. In terms of teasing out the main distinctive qualities of the PDT it is possible to highlight six characteristics: 
(1) Throughout the 20th century the PDT formed the central theme of legislative analysis.

(2) The literature was normatively charged, and the 'decline of parliament' was conceived of as a 'bad' thing.

(3) Scholars frequently assumed the existence of a 'Golden Age' in which parliament had been more powerful and, significantly, its Members more independent of government and of party.

(4) Parliamentary decline was lamented not just in Britain, but in other parliamentary democracies too.

(5) Arguments were rarely supported by detailed empirical evidence.

(6) The parliamentary decline thesis influenced politics and the media.

Taking each of these points in turn, the PDT was a constant and dominant issue throughout the 20th century, but we can note a crucial distinction during that time [p.255] between those accounts that accurately reflected 'reality' and those that did not. So, Sidney Low's The Governance of England (1906), for example, provided a stark analysis of the imbalance in the executive-legislative relationship, pointing to the weakness of the private member, and of the House generally, and the growing strength of the Cabinet' (Low 1906, 83-87), noting further that government 'is scarcely ever turned out of office by Parliament whatever it does' (Low 1906, 81, emphasis in original). Low's account reflected unease towards the profound changes that had occurred in the House of Commons towards the end of the 19th century, in response to the growth of political parties following the 1867 Reform Act. The increasingly dominant role of the parties inside the Commons meant that parliamentary procedure became 'an intensely political problem' (Kelso 2009, 30), and a resource that could be used to shore up governing capacity and fragment the ability of MPs individually to constrain the collective will of the party of government. Although the presence of obstructionist Irish MPs played a role in procedural changes designed to inhibit the capacity of MPs, observers also noted that it was 'the alteration in the nature of the British government itself that prompted procedural reorganisation in favour of the executive (Redlich 1908, 207), particularly demonstrated by reforms implemented in 1902 and 1906-07, which prioritised government business in the House, cropped the legislative process and increased the volume of legislation examined away from the chamber and in standing committees. These procedural changes expanded the capacity for executive action at the expense of the ability of the legislature to control its own business, and thus cemented a process of executive ascendancy inside the legislature which was in direct contrast to the practice just a few decades earlier, when individual MPs could deploy a far broader range of resources to impede government if they so wished.

Consequently, these changes secured at the start of the 20th century provided clear evidence that the growing capacity of modern party government was secured at the expense of the diminishing capacity of individual MPs. Ronald Butt's The Power of 
Parliament $(1969,118)$ described the period 1929-31 as 'the high tide of criticism of the existing parliamentary system', and it is true that these decades hosted unparalleled criticism of politics generally and parliament in particular. In 1923, Winston Churchill declared the House of Commons to be 'dead', or at the very least to be 'marching silently and docilely to execution blindfold' because of the way it accepted government domination of House procedure (James 1974, vol. 4, 3394). In addition, expanded governing capacity did not necessarily equate with 'better' governing and, in this respect, the decline of parliament was viewed as detrimental to the British polity. The economic depression of the 1920s provoked a flurry of recommendations to strengthen parliament vis-à-vis the executive, on the grounds that this would empower it to prevent governments from engaging in poor decision-making and implementing bad public policy. It was in this context that Lord Hewart wrote of 'the new despotism' (1929) and Ramsay Muir criticised How Britain is Governed (1930), with the latter telling a Commons select committee inquiry into the matter that the growth of the executive over the previous decades had 'almost reduced Parliament to insignificance' (HC 161 1930-31, Q. 2642). The PDT was further emphasised in influential books such as Sir Ivor Jennings' Parliamentary Reform (1934), James Ross' Parliamentary Representation (1943), Christopher Hollis' Can Parliament Survive? (1949) and George Keeton's The Passing of Parliament (1952), [p.256] all of which sought, in various ways, to document the growth of the executive at the expense of the legislature, and which also mapped a growing range of measures the authors argued would help return parliament to its rightful place in the political system. The central concern continued to be the marginalisation of the individual MP inside the House and their apparent inability to resist the will of the parliamentary party. The ovine characteristics of MPs were first described by Hollis who complained that:

The member is the obedient servant of the party machine. He tramps into the division lobby voting for or against he knows not what ... As things are now, it would really be simpler and more economical to keep a flock of tame sheep and from time to time to drive them through the division lobbies in the appropriate numbers (Hollis 1949, 64).

This characterisation was one that MPs were never fully to escape. The idea that parliament's decline had rendered it an entirely impotent institution in the political system underpinned analyses of evidence of British economic decline during the early 1960s, and stimulated further criticism of parliament as part of a broader attack on the British establishment. Michael Shank's The Stagnant Society (1961) and Anthony Sampson's Anatomy of Britain (1962) were in this context utterly disparaging of parliament and the role it played in British political life.

During the mid- to late 1960 s a specifically reformist literature emerged in British legislative and constitutional studies. This did not explicitly challenge the PDT but instead sought to set out a more positive and optimistic reform agenda that was 
intended to shift the balance of power back towards the legislature. Its central argument was that 'strong government needs strong opposition' and this position underpinned a range of books and articles (Walkland 1960; Hanson 1963; Crick 1964; Hill and Whichelow 1964; Robson 1964; Marshall 1965; Ryle 1965;Wiseman 1966; Butt 1969) that all, to varying degrees, argued for the reconfiguration of parliamentary work around a specialised committee system. These analyses suggested that the House possessed a dated and amateurish approach to scrutiny of the executive, and that such scrutiny could no longer be conducted solely by individual MPs on the floor of the chamber, but had to be developed and institutionalised in dedicated, all-party fora away from the partisan heat of the House. These sorts of suggestions eventually exerted a tangible impact in the form of the Crossman reforms which introduced an embryonic system of scrutiny committees in the Commons (Flinders 2007; Kelso 2009, 88-98).

Although still promoting and lamenting the PDT, the 1970s witnessed the evolution of a quite different strand of emphasis in the form of the literature on economic decline. The idea that a number of advanced liberal democracies were 'overloaded' and 'ungovernable' was rooted in the perceived failure of economic and political institutions (see Blank 1979; King 1975). Just as the reformist literature in the 1960s contributed to the introduction of reforms that were designed to shift the balance of power from the executive to parliament, a similar pattern can be identified in the 1970s as contextual pressures and ideas regarding executive dominance allowed Norman St John Stevas, as leader of the House, to introduce a number of measures, most notably the departmental select committee system [p.257] established in 1979, which enabled the House to set up a series of committees dedicated to the scrutiny of individual government departments.

However, the new committee system did not lead to a significant or permanent shift in the balance of power (see Flinders 2000; Kelso 2009, 98-101; Norton 2000), and, in part because of its limitations, criticism of parliament continued. Crucially, however, much of the criticism heard at this time tended to be discursive rather than substantive. This is a critical point. Quasi-journalistic accounts perpetuated a simplistic and generally misleading view of legislative capacity. It was in this vein that Bruce Lenman (1992) wrote of The Eclipse of Parliament and Simon Jenkins wrote his superficial but influential Accountable to None (1995). The 21st century did not herald a re-evaluation of the PDT but instead saw the perpetuation of a more extreme version of the thesis. Ian Ward $(2004,42)$ described parliament as 'puerile, pathetic and utterly useless'; Sir Christopher Foster $(2005,291)$ argued that 'power has drained from Parliament'; an allparty group of MPs declared that parliament's 'reputation and influence has crumbled' and that it has 'allowed itself to be driven to the margin' of the political system (Parliament First 2003, 5-6); while the Power Commission Inquiry into Britain's Democracy (Power Commission 2006, 128) massively perpetuated the PDT by noting that 'the Executive in Britain is now more powerful in relation to Parliament than it has been probably since the time of Walpole'. 
The Power Commission's final report is important in relation to the central argument of this article because: (1) it presented the PDT in a more simplistic manner than found in any of the previous declinist texts; and more importantly (2) the evidence provided to the Commission from a number of sources, while certainly endorsing the idea that the executive had grown in strength vis-à-vis the legislature, sought to emphasise that government-parliament relationships were far more complex, and in this regard more balanced, than the Power Commission chose to acknowledge. The Power Commission therefore failed to provide a true account of the complexity of the parliamentary system, and did not underline its multidimensional nature. The Power Report therefore reads more like a piece of prosaic journalism, in which parliament plays the cowering, vulnerable victim of executive dominance.

It is this failure by contemporary commentators, such as those involved in the Power Commission, to take account of the real complexities of parliament that is so problematic in terms of understanding the impact of the PDT. There are at least four sources of detailed empirical evidence that contradict, or at the very least challenge, the PDT. First, there is the work of scholars like Lord Norton (1983) and Philip Cowley (2002) which has clearly demonstrated that Commons voting behaviour has become far more complex, and that back-bench MPs have become more likely to vote against their parties. The notion of MPs as little more than 'lobby fodder' is highly dubious. Second, since the influential work of Anthony King on 'modes of executive-legislative relations' in 1976 a number of scholars have examined and emphasised the role of intra-party machinery and processes as critical but generally unobserved control mechanisms (discussed further below). Third, research on voting behaviour in the House of Lords by Meg Russell and Maria Sciara (2007) has shown that a vastly more complicated picture now exists in terms of how peers vote [p.258] on government legislation, and that the second chamber now has a reasonably substantial impact on government legislation. Finally, possibly the most important challenge to the PDT lies not in scholarly work but in the diaries and memoirs of former politicians. This paints a consistent picture of an executive-legislative relationship that is more balanced, or at the very least respectful, than many academic and journalistic accounts would entertain (for a review see Flinders 2000). Two contemporary examples support this point: David Richards and Helen Mathers' (2010) analysis of David Blunkett's taped memoirs provide a full and frank account of the formal and informal relationships between ministers and parliament; while Chris Mullin's (2010) View from the Foothills provides a similarly detailed account of the role of intra-party channels (notably the Parliamentary Committee and the Parliamentary Labour Party) in moderating relationships.

However, all this evidence failed to impact on popular assumptions about parliament, assumptions that privileged the PDT. Indeed, Cowley's analysis of the voting behaviour of Labour MPs after 1997 revealed just how significant parliament could be as a forum for securing policy change through back-bench behaviour, yet claims that Labour MPs were 'poodles' of the government benches continued unabated. Consequently, the PDT 
not only misses this complexity, but also serves unhelpfully to disseminate a sense that there once existed a 'Golden Age' of parliament- Richard Crossman's 1964 introduction to Bagehot's The English Constitution providing an exemplar-in which 'independent-minded' MPs were far more numerous, and the strength of the parties far more constrained, and that parliament would function far better if those independent MPs could somehow be rediscovered as an antidote to strong party government.

And yet as Hugh Berrington's $(1968,359)$ analysis of voting behaviour in the $19^{\text {th }}$ century revealed, 'the romantic picture of crusading knights [MPs] fighting for the rights of the legislature against executive tyranny is a crude if unwitting distortion'. Consequently, decrying the absence of 'independence' simply obscures the far more complex behaviour of modern party politicians. In arguing that parliament has been relieved of its powers and that this is to be regretted, the PDT makes fundamentally misguided assumptions about the role of parliament in modern British politics. This is an important point with great implications for the core argument of this article. We are not arguing that a shift in the balance of power between the executive and parliament has not occurred; we are arguing that a misunderstanding of constitutional development has led to the overinflation of that shift. This overinflation has created an expectations gap between what the public expects parliament to do and what its role actually is within the political system. Put simply, the PDT would not be so critical, and public confidence in the efficacy of parliament might not be so low, if the expectations of parliament were more realistic (discussed below).

Before moving on to examine how a more accurate understanding of executivelegislative relationships might be articulated through a focus on the expectations gap (Figure 1 above), and thereby possibly help close the gap that has apparently emerged between the governors and the governed in many countries, it is worth concluding this section with five very brief observations which each in their own ways connect with this article's central argument concerning the need to rethink the PDT as the über-narrative within legislative studies.

[p.259] First, one unacknowledged element of the PDT is that it remains unclear what the tangible outcome of a 'strengthened' parliament would be. Put differently, the normative basis of the PDT - that an increasingly powerful executive was a 'bad' or 'undemocratic' development that should be reversed-was very rarely questioned. During the economic crisis of the 1920s and early 1930s, however, arguments concerning executive capacity and the need for 'strong governance' were made as part of an argument that parliament's procedural arrangements and institutional infrastructure were impeding the executive's capacity to control events, but this formed an outlier on an otherwise invariable disciplinary approach. On the whole, PDT advocates championed a range of reforms which they argued would reverse the decline of parliament, and restore it to its rightful place in the political system. Yet, this 'rightful place' was itself mythical—or at the very least highly contested—in that it recalled an 
era of hubris that was utterly unique in its role of marking the emergence of mass representative democracy in Britain.

Second, the PDT failed to take history and path dependency seriously. The constitutional tensions and reforms of the mid- to late 19th century established a legislature that was designed and intended to play a largely acquiescent role in all but the most extreme circumstances. What many reformers failed to recognise was that demands for greater legislative powers and competencies were essentially about institutional recreation, not institutional restoration. However, by linking their claims to the need to recapture the essence of parliament prior to its alleged eclipse and marginalisation, they simply muddied the political waters, and infected the entire discussion with the poison of historical misinformation. Thirdly, what is particularly prominent about the literature associated with the PDT is that it was rarely founded on detailed empirical evidence. If anything there were too many books published on parliamentary politics that promoted and regurgitated the same prosaic arguments and assumptions; and too few offering carefully researched and theoretically informed analyses.

Fourth, possibly the most salient aspect of the PDT is that it had an impact beyond academe. By becoming accepted as the orthodox position the thesis arguably affected how other actors viewed and interacted with parliament. Throughout the 20th century the media portrayed parliament as little more than a 'toothless watchdog' and media coverage of legislative activity declined (see Jenson et al. 2000). Public attitudes towards political institutions are very difficult to explain but it is reasonable to suggest that a constant flow of almost polemical academic and media reports contributed to a decrease in public confidence in parliament, as argued by commentators including Riddell and Wright (discussed above).

Finally, when viewed through the lens provided by Figure 1 (above) a review of the literature on parliament throughout the 20th century reveals that there has been an almost exclusive focus on Option 1 (i.e. increasing supply through an increase in legislative scrutiny capacity vis-à-vis the executive); whereas an awareness of Option 2 (i.e. decreasing demand through mature reflection on the criteria against which parliament was judged) was almost completely absent. To be blunt, the PDT has not served legislative scholars well. It has provided an excuse for lazy thinking and has formed something of an intellectual comfort blanket that fails to reflect the complex resource interdependencies that actually exist. Moreover, in failing [p.260] effectively to challenge the PDT, scholars may have contributed to an erosion of public support in politics in general and declining levels of public confidence in parliaments in particular. The next section examines how scholars might seek to close the gap.

\section{Closing the Gap}

As the first section (above) argued, there are three ways in which an 'expectations 
gap' can be reduced:

Option (1) increasing supply (moving the bottom bar upwards-Figure 1);

Option (2) reducing demand (moving the top bar down);

Option (3) a combination of Options 1 and 2.

The second section suggested that the PDT may have increased public cynicism about parliament and MPs by overinflating expectations while at the same time failing to acknowledge veins of rich empirical material that suggested parliament was somewhat less feeble than the PDT suggested. The aim of this section is to illustrate how a more refined understanding of constitutional history and a more sophisticated account of legislative-executive relationships appears to close this gap. It argues that when judged against a more accurate set of expectations the performance of parliament is possibly better than the PDT can ever reflect. This is achieved by making two basic arguments that have already been alluded to but can now be fleshed out in more detail:

(1) Parliament was not designed, intended or resourced to play the kind of proactive scrutiny role that contemporary expectations appear to demand.

(2) Legislative control of the executive manifests itself in procedures and processes that lie beneath the visible lithosphere of parliamentary activity.

The next two subsections take each of these arguments in turn.

\section{Origins, Expectations and Parliamentary Government}

What roles and expectations does the constitutional configuration of parliamentary government ascribe to the legislature? Identifying the primary roles is relatively straightforward: first, to sustain and support the government in the design and enactment of legislation; and, second, to scrutinise the executive and administration of the state on behalf of the public in between general elections. In terms of expectations, however, parliamentary government as a model or form of constitutional engineering clearly prioritises government capacity over legislative scrutiny. This is reflected in an institutional configuration that adopts a rather lax approach to the separation of powers when compared to presidential models. This point is both implicit and explicit in Bagehot's The English Constitution of 1867, was articulated in Anthony Birch's Representative and Responsible Government (1964) and formed the central theme of David Judge's The Parliamentary State (1993). British democracy and the model of parliamentary government exported to a large number of countries around the world constituted therefore a 'power-hoarding' model of democracy with few antimajoritarian institutions (see Lijphart 1999).

[p.261] The vast literature on the PDT (surveyed above) may have shown the dominance of the executive over the legislature but it rarely, if ever, made the point that this was the product of careful constitutional design. Parliament was never expected to 
impose high levels of scrutiny on ministers or the bureaucracy. Parliament was designed to be subservient to a dominant party in order to facilitate and legitimise 'strong government', a principle that was (and still is) delivered through a simple plurality electoral system. Understanding the logic dictating constitutional design in the 19th century allows us to re-examine many of the PDT's central tenets.

The PDT literature in the 20th century was normatively charged-the 'decline of parliament' was interpreted as a 'bad thing'-and suggested that there had been a serious subversion of democracy which had resulted in parliament's marginalisation. Yet this failed to acknowledge or explain the existence of inherent trade-offs that had been embedded in parliamentary government during the 19th century, and which were themselves underpinned by the fact that the British political system was very firmly rooted in pre-democratic origins (Judge 2005, 19). Notions such as fairness, representation and participation were downgraded in favour of stability, governing capacity and responsiveness (Birch 1964). Furthermore, the fact that these trade-offs had been instituted was by no means secret. Constitutional theorists including Walter Bagehot (1968 [1867]), Frederic Maitland (1908) and Alvert Venn Dicey (1959 [1885]) were keen to design a balanced constitution and within this role the convention of ministerial responsibility was to deliver an effective balance between open/accountable government and strong/efficient government. Bagehot captured this role eloquently when he wrote that the 'incessant tyranny of Parliament over the public offices' could only be prevented by ensuring that ministers, through the support of a large and loyal parliamentary majority, acted as a 'protecting machine' (Bagehot 1968 [1867] , 190191). So, the balance of power has undoubtedly shifted from parliament to the executive, but PDT advocates have overemphasised the extent of scrutiny that parliament was intended or expected to deliver, and by raising the bar so (artificially) high may have exaggerated the expectations-capacity gap.

The House of Commons was simply never intended, expected or resourced to adopt a proactive, regular and centralised model of scrutiny (see McCubbins and Schwartz 1984). And yet this was exactly what much of the PDT-related literature expected parliament to do, and through this created a public expectation that parliament was failing. It is possible to identify a sub-strand of PDT literature that was aware of this tension. Harold Laski's Reflections on the Constitution (1951), Herbert Morrison's Government and Parliament (1954), Jennings' Parliament (1957) and most notably Bernard Crick's The Reform of Parliament (1964) recognised the executive's legitimate entitlement to govern while also acknowledging that the House of Commons could and did enforce the accountability of ministers, but that it generally conserved its powers for issues of major public concern. The emphasis of this group of scholars (the 'moderate optimists') was subtly distinct from the liberal tradition that dominated British political studies during the 20th century. Although the expectations- capacity gap was a theme of this body of work, its awareness of the way the competing demands of democratic accountability and operational efficiency had been balanced through a 'fire alarm' 
model of oversight meant that the perceived gap was not as pronounced as the parliamentary decline thesis suggested. Crucially, [p.262] it was also not as pronounced due to the acknowledgement of intra-party and intra-parliamentary channels of influence and control and these form the focus of the next subsection.

\section{Parties, Pressures and Parliamentary Government}

The PDT generally failed to acknowledge that the model of parliamentary government forged in the 19th century was designed to facilitate a strong executive. As a result scholars (and the media and public) have held parliament to account against a set of expectations that the legislature was simply never intended or resourced to undertake. The expectations gap was therefore widened and parliament appears 'destined to disappoint' (Stoker 2007). Yet, as previously noted, some scholars have produced evidence of the range of processes through which legislative control of the executive occurs. However, despite this useful evidence, there has been a relative lack of detailed empirical or theoretically informed research, and where that research does exist, its findings have not impacted on popular perceptions of the PDT as thoroughly as they could have.

The public face of parliament largely involves the activities of its constituent parties, their various policy commitments and their adaptations to new policy environments over time. However, beneath the observable 'reality' of the parliamentary parties exists a far more complex, fluid environment, through which party leaders and managers must seek to control the energy, interests and ambitions of their party's members. Ministers and their whips enjoy a range of mechanisms through which to channel and control this latent energy (patronage, removal of the whip, deselection, etc.) and this executivelegislative interaction takes place through a range of informal channels (political party caucuses, parliamentary parties, all-party groupings, ad hoc meetings between ministers and members, etc.). The outward appearance of a strong and stable executive governing through a pliant and docile legislature may on occasion therefore veil the existence of deep parliamentary divisions that are played out largely beyond the public eye and are not recorded in the official legislative record. Party groupings within a legislature may in particular seek to achieve what Cowley (2002) has described as the 'internalisation of dissent'. Two factors make the existence of these divisions more likely. First, members of a legislature who may share the same party ticket are rarely a homogeneous body in terms of values, objectives and malleability. Second, in Westminster-style democracies members of the legislature face a number of divided and potentially conflicting loyalties-to their constituents, to the legislature and to their party. Although legislators may suffer from what King (1996) has described as a 'surfeit of partisanship' even this loyalty has limits.

This is a critical point. Throughout the 20th century the PDT tended to be based on a rather lazy review of the externally visible elements of the executive-legislative relationship, in terms of debates, voting outcomes and so on, which provided a very 
shallow view of legislative dynamics. Where scholars undertook research that looked beneath the public façade of parliament through detailed empirical research it revealed a far more sophisticated and balanced relationship. This was evident in Norton's and Cowley's work on voting records, and King's comparative analysis of [p.263] intra-party and intra-parliamentary relationships. King's analysis was particularly influential because it argued that it is 'highly misleading to speak of "executive- legislative relations" tout court' (i.e. without qualification or additional information) and that scholars interested in understanding executive power need to 'think behind' this general heading in order to separate out a number of quite distinct political relationships (King 1976, 11).

It is possible to argue that this advice was heeded more by legislative scholars in Australia, New Zealand and Canada than by those studying British democracy. The research of Stanley Bach (2003 and 2008), David Solomon (1986) and John Uhr (2009) in Australia, for example, challenged the PDT by emphasising the importance of the latent power of MPs and the role of intra-party dynamics. More recently, however, a new generation of British legislative scholars have undertaken detailed research within the Palace of Westminster and have challenged the PDT by uncovering a far more dynamic and at times balanced relationship. It is in this context that Kelso's (2009) Parliamentary Reform at Westminster provides a sophisticated analysis of the executive-legislative relationship; while Philip Cowley and Mark Stuart $(2005,20)$ capture the essence of this article directly by disagreeing with those who 'bemoan the decline of Parliament and its increasing subservience to the executive ... the picture is more complicated-and more balanced-than this melancholy caricature'. Furthermore, if PDT advocates misunderstood that what they were actually arguing for was institutional recreation, rather than institutional restoration, then it is crucial to note that there has in fact been a considerable degree of reform and institutional adaptation in recent decades. The development within the House of Commons of specialised, indepth scrutiny mechanisms, most particularly the continually adapting select committees, but also more recently the public bill committees, has facilitated a marked change in how MPs collectively approach their parliamentary functions. Understanding the capacity of parliament therefore involves researching and analysing the way that the 'realistic capacity bar' in Figure 1 has moved upwards as a direct result of alterations to parliamentary resources and strategies. Yet, so much of the work done by parliament continues to be dismissed as of no consequence, most notably in the media, despite the very changed circumstances of that work. Crucially, then, scholars arguably have a fundamental duty to engage in far more rigorous research into parliament's genuine scrutiny capacity, in order to generate empirical evidence which goes beyond cosmetic, journalistic assessments that pass as academic research, and, crucially, then to communicate that research as effectively as possible.

In order to locate the specific argument of this section within the broader argument of this article it is useful to recall Figure 1. First, we argue that scholars, by adopting and 
perpetuating the PDT in a very simplistic manner, have increased public expectations (they have lifted the top bar) by failing to explain or emphasise that parliamentary government, as it emerged out of the 19th century, was explicitly intended to deliver 'strong government'. As a result the House of Commons was never empowered, resourced or intended to exert a constant or arduous role in relation to scrutinising the executive; it was designed to wield a latent power that would only be deployed in the most serious cases of error or omission. The failure of the PDT to acknowledge this fact cultivated a level of expectations and demand that parliament was simply never intended to deliver. Put slightly differently, [p.264] scholars could possibly have played a role in reducing demand (Option 2, above) by promoting an understanding of the principles and trade-offs that had been embedded within the model of parliamentary democracy. We also argue that while inflating public expectations (raising the top bar) scholars failed to close the gap from below (Option 1, above) due to a failure to acknowledge the existence and capacity of informal, but no less important, intra-party and intra-parliamentary channels of legislative control and oversight. Supply, in terms of legislative behaviour and capacity, was actually greater than the PDT acknowledged.

Taken together these two points form the crux of this article's critique of the PDT. If the top bar is pulled down (Figure 1) by accepting the more limited constitutional role of parliament, and the bottom bar is pulled up, to acknowledge the existence and importance of less visible intra-party and intra-legislative control mechanisms, then the 'expectations gap' would be narrower. While the remaining extent of that gap, and its impact, remains open to debate, what this article is really focusing on is the manner in which the PDT as a dominant conceptual lens was imbued with certain assumptions that were rarely comprehensively contested. As a result this article is as much about the role and power of dominant ideas, idioms and frames of reference within political science as it is about legislative studies per se. Having made this argument it is necessary to reflect on why it matters.

\section{So What?}

Sartori's (1970) notion of the 'unconscious thinker' points to generations of scholars who have inherited and accepted conventional wisdoms and assumptions without subjecting the underlying foundations of their discipline to detailed empirical analysis. In many ways, this is exactly what has happened across decades of British political studies (and elsewhere) with respect to the PDT. This article has utilised a theory of public expectations in order to suggest that the PDT is highly problematic, not only because it is a manifestly defective account of parliament, but because it widens the expectations gap and through this contributes to what could be called a 'perception gap'. In making this bold and provocative argument this has clearly been a wide-ranging article and, like painting on a large canvas, has required the use of a fairly broad brush, in analytical and empirical terms. It would have been interesting, for example, to include 
a comparative perspective-utilising the pessimistic tracts of scholars like John Curtin (1938), Richard Bland (1959) and Magnus Cormack (1976) in Australia, and Tom McRae's (1994) A Parliament in Crisis and Geoffrey Palmer's Unbridled Power? (1987) in New Zealand-but it is hoped that by emphasising the notion of public expectations within the parameters of debates concerning the capacity of parliament, the epistemology of legislative studies and the public responsibilities of political scientists, this article will stimulate more scholarly interest in this topic, thereby filling in the detail and achieving a more fine-grained (comparative) understanding than can be achieved in a single article.

In terms of teasing out the broader implications of this article it is possible to locate it within the contours of three broad but interlinked fields of inquiry. The first of these focuses on the theories, methods and conceptual tools through which we seek [p.265] to understand political phenomena. This article has attempted to demonstrate a form of conceptual travelling-hopefully not stretching - in which the insights and value of 'gap analysis' have been transferred to a new intellectual terrain (i.e. legislative studies). In this sense the article has attempted to do something different, take some risks and fly some intellectual kites.

Moreover the results of this gap analysis provide empirical evidence for a broad ranging disciplinary critique which has cast doubt on a foundational element of legislative studies (i.e. the PDT) that has remained 'essentially uncontested' for at least a century. More specifically this article has not sought to prove the PDT 'wrong' but simply to argue that a more refined analysis of British constitutional history combined with a review of the realities of Westminster politics suggests that the 'gap' in terms of resource dependencies between executive and legislature is not quite as large as many academics and observers have frequently suggested. Our plea to 'mind the gap' therefore appeals to the broader academic community to reflect more closely on the intellectual assumptions of their discipline and particularly to evaluate political institutions against a constitutionally sensitive and empirically accurate set of expectations. This plea exposes the socio-political backcloth to this article and brings it full circle and back to the introduction's discussion of the manner in which an increasingly vocal range of observers have blamed university professors of politics for inflaming public cynicism and disillusionment with politics (cf. Riddell 2010; Wright 2009).

This article has therefore posed fresh and distinctive questions about the role of political scientists in terms of cultivating public understanding and at the very least not perpetuating lazy thinking. Scholars have a public duty to correct rather than propagate the myths that surround their chosen subject matter. Colin Hay $(2007,4)$ points out that political analysts cannot bear full or direct responsibility 'for whatever pathologies afflict the contemporary polity', but they do have a responsibility 'when it comes to diagnosing and seeking solutions' to those pathologies. It is with addressing this point 
regarding professional responsibilities and scholarly precision that this article has been primarily concerned. Narratives of parliamentary decline may have dominated popular and scholarly discourse throughout the 20th century but maybe the time has come to 'think again' in a more precise, empirically grounded but theoretically informed manner.

\section{Bibliography}

Bach, S. (2003) Platypus and Parliament: The Australian Senate in Theory and Practice (Canberra: Senate Parliament House).

Bach, S. (2008) 'Senate amendments and legislative outcomes in Australia, 1996-2007', Australian Journal of Political Science, 43:3, 395-423.

Bagehot, W. (1968 [1867]) The English Constitution (Oxford: Oxford University Press).

Barnes, C. and Gill, D. (2000) 'Declining governmental performance? Why citizens don't trust government', Working Paper No.9 (Auckland: State Services Commission).

Behn, R. (2001) Rethinking Democratic Accountability (Washington, DC: Brookings Institute).

Berrington, H. (1968) 'Partisanship and dissidence in the nineteenth century House of Commons', Parliamentary Affairs, 21:2, 338-374.

Birch, A. H. (1964) Representative and Responsible Government (London: George Allen and Unwin).

Birch, S. and Allen, N. (2010) 'How honest do politicians need to be?', Political Quarterly, 81:1, 49-56.

Bland, F. (1959) 'The decline of parliament', Australian Liberal, April, 7.

Blank, S. (1979) 'Britain's economic problems: Lies and damn lies', in I. Kramnick (ed.), Is Britain Dying? Perspectives on the Current Crisis (London: Cornell University Press), 74-91.

Bok, D. (1997) 'Measuring the performance of government', in J. Nye Jr, P. D. Zelikow and D. C. King (eds), Why People Don't Trust Government (Cambridge, MA: Harvard University Press), 55-76.

Bovens, M. (2006) 'Analysing and assessing public accountability', Eurogov Paper No.C06-01.

Butt, R. (1969) The Power of Parliament (London: Constable). 
Cormack, M. (1976) 'The standing of parliament in the Commonwealth of Australia', Parliamentarian, 57:1, 168-173.

Cowley, P. (2002) Revolts and Rebellions (London: Politico's).

Cowley, P. and Stuart, M. (2005) 'Parliament', in A. Seldon and D. Kavanagh (eds), The Blair Effect, 2001-2005 (Cambridge: Cambridge University Press), 20-42.

Crick, B. (1964) The Reform of Parliament (London: Weidenfeld \& Nicholson).

Crossman, R. (1964) 'Introduction', in W. Bagehot, The English Constitution (London: Watts), 1-57.

Curtin, J. (1938) 'The decline of parliamentary government: A protest', Australian Quarterly, 10:1, 5-9.

Dicey, A. V. (1959 [1885]) An Introduction to the Study of the Law of the Constitution (London: Macmillan).

Downs, A. (1957) An Economic Theory of Democracy (New York: Harper).

Flinders, M. (2000) 'The enduring centrality of individual ministerial responsibility within the British constitution', Legislative Studies, 6:3, 73-92.

Flinders, M. (2007) 'Analysing reform', Political Studies, 55:2, 174-200.

Flinders, M. (2009) 'Bridging the gap', Representation, 45:3, 339-348.

Foster, C. (2005) British Government in Crisis (Oxford: Hart Publishing).

Gallie, W. B. (1956) 'Essentially contested concepts', Proceedings of the Aristotelian Society, 56, 167-198.

Hanson, A. H. (1963) 'The purpose of parliament', Parliamentary Affairs, 17:3, 279-295.

Hay, C. (2007) Why We Hate Politics (London: Polity Press).

HC 161 (1930-31) Special Report from the Select Committee on Procedure on Public Business (London: HMSO).

Hewart, L. (1929) The New Despotism (London: Benn).

Hill, A. and Whichelow, A. (1964) What's Wrong with Parliament? (London: Penguin).

Hollis, C. (1949) Can Parliament Survive? (London: Hollis \& Carter).

James, O. (2009) 'Evaluating the expectations disconfirmation', Journal of Public Administration Research and Theory, 19:1, 107-123. 
James, R. R. (ed.) (1974) Winston S. Churchill: His Complete Speeches, 1897-1963 (London: Chelsea House Publishers).

Jenkins, S. (1995) Accountable to None (London: Penguin).

Jennings, I. (1934) Parliamentary Reform (London: Victor Gollanz).

Jennings, I. (1957) Parliament (Cambridge: Cambridge University Press).

Jenson, J., Papillon, M., Thomas, P. and Lemieux, V. (2000) Modernising Governance (Ottawa: Canadian Centre for Management Development).

Judge, D. (1993) The Parliamentary State (London: Sage).

Judge, D. (2005) Representation: Theory and Practice in Britain (London: Routledge).

Keeton, G. W. (1952) The Passing of Parliament (London: Benn).

Kelso, A. (2009) Parliamentary Reform at Westminster (Manchester: Manchester University Press).

King, A. (1975) 'Overload: Problems of governing Britain in the 1970s', Political Studies, 23:2, 284- 296.

King, A. (1976) 'Modes of executive-legislative relations', Legislative Studies Quarterly, $1: 1,11-36$.

King, A. (1996) Is Britain a Well Governed Country? (London: Lloyds TSB Forum).

Koppell, J. G. S. (2005) 'Pathologies of accountability', Public Administration Review, 65:1, 94-108.

Laski, H. (1951) Reflections on the Constitution (Manchester: Manchester University Press).

Lenman, B. P. (1992) The Eclipse of Parliament (London: Edward Arnold).

Lijphart, A. (1999) Patterns of Democracy (London: Yale University Press).

Low, S. (1906) The Governance of England (London: T. Fisher Unwin).

Maitland, F. W. (1908) The Constitutional History of England (Cambridge: Cambridge University Press).

Marshall, G. (1965) 'Parliament and the constitution', Political Quarterly, 36:2, 255-266.

McCubbins, M. D. and Schwartz, T. (1984) 'Congressional oversight overlooked: Police patrols versus fire alarms', American Journal of Political Science, 28:1, 165-179. 
McRae, T. M. (1994) A Parliament in Crisis: The Decline of Democracy in New Zealand (Wellington: Sheildag Publications).

Morrison, H. (1954) Government and Parliament (London: Oxford University Press).

Muir, R. (1930) How Britain is Governed (London: Constable).

Mullin, C. (2010) A View from the Foothills (London: Profile).

Norris, P. (1999) Critical Citizens (Oxford: Oxford University Press).

Norton, P. (1983) 'The Norton view', in D. Judge (ed.), The Politics of Parliamentary Reform (London: Heinemann), 54-69.

Norton, P. (2000) 'Reforming parliament in the United Kingdom', Legislative Studies, 6:1, $1-15$.

Palmer, G. W. R. (1987) Unbridled Power: An Interpretation of New Zealand's Constitution and Government (Auckland: Oxford University Press).

Parliament First (2003) Parliament's Last Chance (London: Parliament First).

Pharr, S. J. and Putnam, R. D. (2000) Disaffected Democracies (Princeton, NJ: Princeton University Press).

Power Commission (2006) Power to the People (London: The Power Inquiry).

Public Services Trust (2010) What Do People Want, Need and Expect from Public Services? (London: Public Services Trust).

Rawnsley, A. (2001) Servants of the People (London: Penguin).

Redlich, J. (1908) The Procedure of the House of Commons: Volume 1: A Study of its History and Present Form (London).

Richards, D. and Mathers, H. (2010) 'Political memoirs and New Labour: Interpretations of power and the "club rules" ', British Journal of Politics and International Relations, $12: 4,498-522$.

Riddell, P. (2010) 'In defence of politicians: In spite of themselves', Parliamentary Affairs, $63: 3,545-557$.

Robson, W. (1964) 'The reform of government', Political Quarterly, 35:2, 193-211.

Ross, J. F. S. (1943) Parliamentary Representation (New Haven, CT: Yale University Press).

Russell, M. and Sciara, M. (2007) 'Why does the government get defeated in the House of Lords?', British Politics, 2:3, 299-322. 
Ryle, M. (1965) 'Committees of the House of Commons', Political Quarterly, 36:3, 295308.

Sampson, A. (1962) Anatomy of Britain (London: Hodder and Stoughton).

Sartori, G. (1970) 'Concept misformation in comparative politics', American Political Science Review, 64:4, 1033-1053.

Shanks, M. (1961) The Stagnant Society (Harmondsworth: Penguin).

Solomon, D. H. (1986) The People's Palace: Parliament in Modern Australia (Melbourne: Melbourne University Press).

Stoker, G. (2007) 'Politics in mass democracies', Representation, 42:2, 181-194.

Uhr, J. (2009) 'Comparing Congress: Bryce on deliberation and decline in legislatures', Boston University Law Review, 89:4, 847-862.

Walkland, S. A. (1960) 'The House of Commons and the estimates', Parliamentary Affairs, 13:4, 477- 488 .

Ward, I. (2004) The British Constitution (London: Hart).

Wiseman, H. V. (1966) Parliament and the Executive (London: Routledge).

Wright, T. (2009) 'Doing politics differently', Political Quarterly, 80:3, 319-328. 